\title{
Strategi Kepala SD-LB dalam Meningkatkan Kinerja Guru
}

\author{
Vivid Agus Tridora' ${ }^{1}, \mathrm{Kms}$. Badarudin ${ }^{2}$, Amilda $^{3}$ \\ 1,2,3Universitas Islam Negeri Raden Fatah Palembang, Sumatera Selatan, Indonesia \\ vividagustridora0508@gmail.com
}

\begin{abstract}
This study aims to identify, describe and analyze and provide alternative solutions to the factors supporting and inhibiting the principal's strategy in improving teacher performance at SD-LB Bina Autis Mandiri (BAM). This research uses a case study research type by design because the researchers look at cases, events and everyday events at Bina Autism Mandiri as the ones that will be used as research. The results of this study are the strategy used by the principal in improving teacher performance at SD-LB Bina Autis Mandiri Palembang, namely conducting a strict selection of teachers through academic tests and also medical debriefing. Applying democratic leadership by accepting criticism, suggestions from every effective teacher for the learning process, providing persuasive training to teachers, also using individual approach strategies for teachers to be fostered and directed directly in an effort to improve the teacher's strategy. Teacher performance is quite good through teacher competency assessment. In addition, teacher performance is measured through evaluation results from the supervision of the principal. Supporting factors are teachers who have ideas and creativity in managing the learning process, school facilities and persuasive training for teachers, democratic attitudes of school principals, and awarding rewards for teachers. While the inhibiting factors come from the teacher's internal factors, the age of the teacher who has difficulty understanding technology media, the teacher's personal problems that are carried over to teaching and learning activities and have an impact on the lack of concentration in the classroom.
\end{abstract}

Keywords: Principal Strategy, Teacher Performance

\begin{abstract}
Abstrak. Penelitian ini bertujuan untuk mengetahui, mendeskripsikan dan menganalisis serta memberikan alternatif solusi faktor pendukung dan penghambat strategi kepala sekolah dalam meningkatkan kinerja guru di SD-LB Bina Autis Mandiri (BAM). Penelitian ini menggunakan jenis penelitian studi kasus dengan rancangan karena peneliti mencermati kasus, peristiwa dan kejadian sehari-hari pada Bina Autis Mandiri sebagai yang akan dijadikan penelitian. Hasil penelitian ini adalah strategi yang digunakan kepala sekolah dalam meningkatkan kinerja guru di SD-LB Bina Autis Mandiri Palembang yaitu melakukan seleksi ketat guru-guru melalui tes akademik dan juga pembekalan medis. Menerapkan kepemimpinan demokratis dengan menerima kritik, saran dari setiap guru-guru yang efektif bagi proses pembelajaran, memberikan pelatihan-pelatihan yang persuasif kepada guru, juga menggunakan strategi pendekatan individual bagi guru untuk dibina dan diarahkan langsung dalam upaya meningkatkan strategi guru tersebut. Kinerja guru cukup baik melalui penilaian kompetensi guru. Selain itu, kinerja guru diukur melalui hasil evaluasi dari supervisi kepala sekolah. Faktor pendukung yakni guru yang memiliki ide dan kreatifitas dalam mengelola proses pembelajaran, fasilitas sekolah dan pelatihan yang persuasif bagi guru, sikap demokratis kepala sekolah, serta pemberian reward penghargaan bagi guru. Sedangkan factor penghambat berasal dari faktor intern guru, usia guru yang sulit memahami media teknologi, permasalahan pribadi guru yang terbawa sampai pada aktifitas belajar mengajar dan berdampak pada kurangnya konsentrasi di kelas.
\end{abstract}

Kata Kunci: Kinerja Guru, Strategi Kepala Sekolah

\section{PENDAHULUAN}

Indonesia merupakan negara yang merespon dan mendukung komitmen dunia terhadap pendidikan salah satunya pendidikan inklusi dengan 
mengeluarkan Undang Undang Nomor 20 tahun 2003 tentang Sistem Pendidikan Nasional dalam penyediaan pendidikan bagi anak berkebutuhan khusus. Pasal 15 tentang pendidikan khusus disebutkan bahwa pendidikan khusus merupakan pendidikan untuk peserta didik yang berkelainan atau peserta didik yang memiliki kecerdasan luar biasa yang diselenggarakan secara inklusif atau berupa satuan pendidikan khusus pada tingkat pendidikan dasar dan menengah. Pada pasal ini yang memungkinkan terobosan untuk terbentuknya pelayanan pendidikan bagi anak berkelainan berupa penyelenggaraan pendidikan inklusif (Sholawati, 2019).

Pada lembaga yang menyelenggarakan pendidikan inklusi memberikan ruang khusus bagi para $\mathrm{ABK}$ dan anak regular untuk bersosialisasi bersamasama agar tidak terjadi kesenjangan akibat pola pikir yang menyatakan bahwa ABK tidak mampu bersosialisasi dengan teman bermain yang normal. Salah satu yang menjadi fokus pada penyelenggaraan pendidikan inklusi adalah SDM (sumber daya manusia) yang memiliki potensi dalam mendidik peserta didik. Bukan hanya memperhatikan para $\mathrm{ABK}$, mereka di tuntut bisa menyeimbangkan antara peserta didik yang regular dengan ABK pada pembelajaran dan di ruang kelas yang sama.

Menjadi guru untuk anak-anak dengan kebutuhan khusus adalah salah satu profesi yang menyebabkan stress tinggi. Guru untuk pendidikan khusus biasanya harus menerima tantangan dalam menangani anak-anak dengan kebutuhan khusus. Guru juga memiliki kesempatan untuk membangun hubungan dekat dengan anak-anak. Profesi ini biasanya sangat dihargai, namun sangat menghabiskan energi secara fisik maupun emosional (Widyawati, 2019).

Dilihat dari hal tersebut, sebagai pemimpin pada sekolah tersebut maka sudah menjadi kewajiban kepala sekolah untuk bisa mengelola semua sumber daya manusia dan fasilitas agar berfungsi sesuai kebutuhan sekolah (Wahyusumidjo, 2008). Khususnya pada sekolah inklusi yang mendidik ABK dan regular pada kondisi yang sama, maka kepala sekolah harus mampu mengatur semua hal agar jauh dari resiko kegagalan (Karo-karo, 2018).

Kemampuan kepala sekolah sebagai seorang pemimpin dipengaruhi oleh strategi yang diterapkannya di lembaga (Aisyah, 2016). Salah satu strategi untuk meningkatkan kualitas pendidikan adalah penerapan manajemen strategi. Alasan yang mendasar adalah bahwa konsep manajemen strategi menawarkan kepada sekolah untuk menyediakan pendidikan yang lebih baik dan lebih memadai bagi peserta didik. Konsep ini menekankan kepada upaya sekolah dalam mengidentifikasi apa yang ingin mereka capai, dan bagaimana seharusnya mereka mencapai hasil yang bernilai guna dalam 
(Strategi Kepala SD-LB dalam Meningkatkan Kinerja Guru)

tatanan ruang lingkup pendidikan, sehingga sekolah dapat memahami kekuatan bersaing dan mengembangkan keunggulan kompetitif berkelanjutan secara sistematis dan konsisten (Baharuddin, 2019).

Melaksanakan fungsi manajemen di sekolah inklusi terbalik yang didominasi lebih banyak ABK daripada siswa regular akan menentukan keberhasilan visi mereka "Memberikan wadah yang tepat pada anak berkebutuhan khusus untuk mendapatkan pengajaran secara holistik", kepala sekolah sebagai pemimpin harus bisa menerapkan berbagai cara dalam memberdayakan guru-guru yang berkompeten memberikan pemahaman akademik dan pelatihan bakat siswa yang didukung dengan fasilitas sekolah, untuk mengetahui hal itu penulis tertarik untuk mengadakan penelitian dengan judul Strategi Kepala SD-LB dalam Meningkatkan Kinerja Guru.

\section{KAJIAN LITERATUR}

1. Kinerja Guru di Sekolah Inklusi

Kinerja berasal dari bahasa Inggris "performance" yang berarti prestasi kerja atau pelaksanaan kerja atau pencapaian kerja atau hasil kerja/penampilan kerja (Fitriani, 2016). Maka dapat dikatakan bahwa kinerja merupakan perwujudan atau perpaduan yang sinergik dari kemampuan dan motivasi dalam melaksanakan pekerjaan. Dengan demikian kinerja seseorang terlihat dari produktivitasnya dalam melaksanakan pekerjaannya. Dalam hubungannya dengan produktivitas, ada dua faktor yang sangat menentukan kinerja yaitu kemampuan dan motivasi.

Kinerja adalah bentuk produktifitas seseorang yang sinergis dengan motivasi dan kemampuannya, sedangkan menurut Peraturan Menteri Negara Pendayagunaan Aparatur Negara dan Reformasi Birokrasi Nomor 16 Tahun 2009, penilaian kinerja guru adalah penilaian yang dilakukan terhadap setiap butir kegiatan tugas utama guru dalam rangka pembinaan karir, kepangkatan, dan jabatannya. Pelaksanaan tugas utama guru tidak dapat dipisahkan dari kemampuan seorang guru dalam penguasaan dan penerapan kompetensinya. Dalam hal ini adalah kompetensi yang sangat diperlukan bagi guru seperti yang diamanatkan oleh Peraturan Menteri Pendidikan Nasional Nomor 16 Tahun 2007 tentang Standar Kualifikasi Akademik dan Kompetensi Guru. Penguasaan dan penerapan kompetensi sangat menentukan tercapainya kualitas proses pembelajaran, pembimbingan siswa, dan pelaksanaan tugas tambahan yang relevan yang sesuai dengan fungsi sekolah/madrasah (Asiah, 2017).

Penjelasan Peraturan Menteri Negara PAN/RB/16/2009 yang menyetujui bahwa kinerja adalah salah satu bentuk penguasaan kompetensi 
guru. Dalam dunia pendidikan posisi sekolah inklusi juga menentukan kriteria kemampuan atau kompetensi gurunya dimana menurutnya kompetensi guru adalah kemampuan mengelola pembelajaran siswa-siswi berkebutuhan khusus yang terdiri atas aspek pengetahuan, pemahaman, kemampuan, nilai, sikap, dan minat, sebagai seperangkat tindakan yang cerdas, penuh tanggung jawab, yang dimiliki guru sebagai syarat untuk dianggap mampu oleh masyarakat dalam melaksanakan tugas-tugas guru pada Kepmendiknas No. 045/U/2002 (Damayanti, 2016).

Mengenai kompetensi guru pada sekolah berkebutuhan khusus/ inklusi yang dalam hal diberikan istilah sebagai guru pembimbing khusus yaitu "guru yang memiliki kualifikasi akademik dan kompetensi pendidikan khusus yang diberi tugas oleh kepala sekolah/kepala dinas/kepala pusat sumber untuk memberikan bimbingan/advokasi/konsultasi kepada pendidik dan tenaga kependidikan disekolah umum dan sekolah kejuruan yang menyelenggarakan pendidikan inklusif" (Jannah, 2013).

Kembali melanjutkan posisi guru yang dinilai kinerjanya, kinerja guru berdasarkan beberapa hal, meliputi; (1) efek terhadap tingkat ketercapaian hasil belajar siswa; dan (2) karakteristik aktivitas mengajar yang bertujuan pada hasil. Kinerja guru dikatakan berhasil apabila, memberikan efek terhadap perkembangan potensi siswa dalam konteks psikologis dan fisik, yakni bersikap positif terhadap apa yang dipelajarinya, baik dilihat dari tujuan serta manfaatnya (Asiah, 2017).

Menegaskan pendapat di atas, kinerja merupakan sesuatu yang kompleks dan dipengaruhi banyak faktor, baik internal dan eksternal. Seperti pendapat sebelumnya bahwa kinerja dipengaruhi oleh motivasi dan kemampuan, menurut Abd Madjid maksud kemampuan adalah pengetahuan dan keterampilan, pendidikan, pengalaman, latihan dan minat. Sedangkan motivasi dipengaruhi oleh lingkungan fisik pekerjaan, lingkungan sosial pekerjaan yang terdiri dari: kepemimpinan, organisasi formal atau lingkungan organisasi yang mencakup struktur organisasi, iklim kepemimpinan dan efisiensi organisasi serta manajemen (Madjid, 2016).

Beberapa pendapat di atas dapat peneliti tarik benang merahnya yakni kinerja guru merupakan hasil dari kemampuan guru berupa kompetensi yang ada dalam dirinya baik dari profesi maupun kemampuan yang diperolehnya selama ini (pengalaman, keterampilan, minat, latihan) serta motivasi yang diperoleh dari dalam dirinya maupun yang sebagian besar dari lingkungan sekitarnya terutama adalah dunia kerjanya. Dan iklim kerja terutama pemimpin adalah faktor yang berpengaruh dalam kinerja guru itu sendiri, yang dalam hal ini pada lembaga inklusi keberadaan kepala sekolah sebagai 
(Strategi Kepala SD-LB dalam Meningkatkan Kinerja Guru)

pemimpin berperan utama mengembangkan kemampuan guru yang memiliki tugas kompleks sebagai pendidik dan terapi bagi siswa ABK dan regular.

\section{Konsep Strategi Kepala Sekolah}

Strategi yaitu proses yang menentukan adanya perencanaan terhadap para top manajer yang sungguh berarah pada tujuan jangka panjang perusahaan yang disertai dengan penyusunan akan upaya bagaimana agar mencapai tujuan yang diharapkan. Dengan strategi ini maka ada yang hampir dimulai dari apa yang selalu untuk bisa terjadi dan bukan yang dimulai dari apa yang terjadi (Taufiqurokhman, 2016).

Maksud pernyataan di atas menjelaskan strategi adalah hal penting yang menentukan proses awal sebelum kejadian/ aktifitas dalam sebuah organisasi, bersifat mengawali perencanaan dengan membentuk upaya-upaya yang mengarah pada keberhasilan tujuan organisasi.

Pada dunia manajemen memiliki beragam cabang dan beberapa kajian yang bersifat khusus misalnya ialah manajemen keuangan, manajemen sumber daya manusia, manajemen produksi, manajemen transportasi, dan muncul kajian khusus yang lain yaitu Manajemen Strategik/ strategi.

Dalam teori Fred David (2000) Strategic Management terkait dengan ilmu manajemen yang membahas strategi yang diartikan sebagai seni dan ilmu dari perumusan, pengaplikasian, dan evaluasi dari berbagai keputusan yang memungkinkan perusahaan untuk dapat mencapai tujuannya. Menurut tujuan Manajemen Strategi adalah memanfaatkan dan membuat kesempatan/oportunitas baru dan berbeda untuk masa depan.

Pada lingkup dunia manajemen perusahaan/ bisnis, menempatkan manajemen strategi pada dunia pendidikan. Alasan yang mendasar adalah bahwa konsep manajemen strategi menawarkan kepada sekolah untuk menyediakan pendidikan yang lebih baik dan lebih memadai bagi peserta didik. Konsep ini menekankan kepada upaya sekolah dalam mengidentifikasi apa yang ingin mereka capai, dan bagaimana seharusnya mereka mencapai hasil yang bernilai guna dalam tatanan ruang lingkup pendidikan, sehingga sekolah dapat memahami kekuatan bersaing dan mengembangkan keunggulan kompetitif berkelanjutan secara sistematis dan konsisten.

Jika membahas lembaga pendidikan, maka sudah jelas sebagai manajer sekaligus pimpinan di lembaga pendidikan yakni kepala sekolah mempunyai peranan penting yang sangat strategis dalam upaya meningkatkan mutu pendidikan sekolah. Sebagai Pemimpin suatu organisasi sangat bertanggung jawab atas proses manajemen strategis, mulai dari perumusan sampai penerapan hingga pada perfomanya, kemudian kembali ke perumusan lagi. 
Strategi manajemen sekolah dilakukan dengan memperkuat strategi penyusunan rencana penyelenggaraan program sekolah, pengorganisasian tugas dan tanggung jawab setiap personal sekolah dengan memperkuat alokasi anggaran dan penyediaan fasilitas belajar, pemberdayaan personal dan memadukan fungsi organisasi dengan keputusan strategis, strategi pengetahuan disusun secara sistematis sesuai dengan kecakapan menyesuaikan masalah kebutuhan sekolah, sedangkan strategi informasi memperkuat keterampilan untuk memperbaiki berbagai kegiatan staf dan kemampuan organisasi (Baharuddin, 2019).

Adapun strategi-strategi yang digunakan pemimpin dalam pendidikan diantaranya:

1. Perumusan misi lembaga

2. Penentuan profil lembaga

3. Analisis dan pilihan strategic

4. Penetapan sasaran jangka panjang

5. Penentuan strategi induk

6. Penentuan strategi operasional

7. Penentuan sasaran jangka pendek (salah satu cara yang melakukan konkretisasi ialah dengan menetapkan sasaran tahunan)

8. Perumusan kebijaksanaan,

9. Pelembagaan strategi

Dalam pelembagaan terdapat tiga unsur yang harus dimiliki oleh setiap lembaga yang harus mendapat perhatian, yaitu:

a. Struktur organisasi

b. Gaya kepemimpinan

c. Kultur organisasi

10. Pencapaian sistem pengawasan

11. Penciptaan sistem penilaian

12. Penciptaan sistem umpan balik

Untuk memperoleh umpan balik tentang bagaimana strategi yang telah ditetapkan tersebut diimplementasikan. Dengan umpan balik yang factual, tepat waktu dan objekif, pemimpin dapat memperoleh pengetahuan tentang keberhasilan lembaga maupun ketidakberhasilan. Strategi yang baik adalah bila dapat melahirkan metode yang baik pula. Sebab metode adalah pelaksanaan strategi (Rais, 2019).

\section{METODE PENELITIAN}

Penelitian ini menggunakan pendekatan kualitatif dengan pertimbangan karena peneliti ingin memperoleh data kualitatif berupa kata-kata lisan, 
(Strategi Kepala SD-LB dalam Meningkatkan Kinerja Guru)

tulisan, kegiatan atau aktifitas, tindakan, gambar foto, bagan, skema, artefak dan dokumen terkait dengan strategi kepala sekolah dalam meningkatkan kinerja guru berdasarkan manajemen. Penelitian ini menggunakan jenis penelitian studi kasus dengan rancangan karena peneliti mencermati kasus, peristiwa dan kejadian sehari-hari pada Bina Autis Mandiri sebagai yang akan dijadikan penelitian. Teknik analisis data yang digunakan dalam penelitian ini adalah deskriptif kualitatif artinya data yang diperoleh melalui penelitian tentang analisis strategi kepala sekolah dalam meningkatkan kinerja guru di SD-SLB Bina Autis Mandiri (BAM), dilaporkan apa adanya kemudian di analisis secara deskriptif untuk mendapatkan gambaran mengenai fakta yang ada, teknik analisis data dikutip dari Sugiyono (2014:404) menggunakan model Miles and Huberman yang meliputi data reduksi (reduksi data), data display (penyajian data) dan conclusion drawing/ verification (kesimpulan dan verifikasi). Teknik pengecekan keabsahan data dalam penelitian kualitatif dilaksanakan berdasarkan beberapa kriteria, sesuai dengan objek yang diteliti, yaitu terkait dengan strategi kepala sekolah dalam meningkatkan kinerja guru dengan uji keabsahan data dalam penelitian kualitatif melalui standar penelitian (kredibilitas, transferabilitas, dependabilitas, dan konfirmabilitas) (Suyitno, 2018).

\section{HASIL DAN PEMBAHASAN}

Setiap guru di SD-LB Bina Autis Mandiri Palembang terlebih dahulu harus melalui proses tes seleksi akademis maupun tes medis (terapi pengenalan terhadap anak berkebutuhan khusus). Setelah melalui tes, calon guru akan diberikan waktu 2 bulan masa percobaan mengajar untuk memperlihatkan kemampuannya sebagai pendidik bagi anak berkebutuhan khusus dan anak regular (normal). Apabila bisa menjalani proses percobaan dengan baik maka guru bisa diterima sebagai pendidik di SD-LB Bina Autis Mandiri Palembang. Guru yang terpilih untuk menjadi tenaga pendidik di SD-LB Bina Autis Mandiri Palembang adalah mereka yang memiliki 4 kompetensi guru (pedagogik, kepribadian, professional, dan sosial). Melalui hal itu, pihak sekolah bisa mengukur, mengarahkan, mengasah serta memperbaiki kemampuan guru lebih baik lagi.

Kepala sekolah menerapkan strategi pendekatan khusus bagi guru yang mengalami permasalahan berkaitan dengan menurunnya kinerja guru. Dengan adanya pendekatan individual ini, maka guru bisa membahas alasan menurunnya kinerja dirinya dan kepala sekolah secara langsung bersama guru bisa mencari solusi terbaik untuk mengatasi hal itu bersama-sama. Guru diberi ruang untuk membicarakan perkembangan kinerja mengajar, hasil dari 
pembahasan itu kemudian akan dievaluasi kepala sekolah untuk diberikan penilaian meningkat atau tidaknya kinerja guru. Apabila perlu ditingkatkan maka akan ada pengarahan atau pembinaan yang diberikan oleh kepala sekolah terhadap guru tersebut. Kepala sekolah menurut pandangan guru adalah tipe yang memberikan keputusan atas dasar ide dari guru-guru ataupun kebijakan dari dirinya dan yayasan. Atas keputusan yang dianggap sebagian guru termasuk yang sulit diterima akan dijelaskan kepala sekolah alasan dari keputusan yang ditetapkan dirinya dengan cara komunikasi aktif. Kepala sekolah menerapkan strategi untuk permasalahan guru dengan cara yang komunikatif. Beliau memberikan solusi kepada guru yang mengalami permasalahan dan mengganggu aktifitas mengajar dengan cara mengeluarkan atau mengistirahatkan guru tersebut dari kegiatan belajar mengajar. Dengan demikian, sekolah memberikan waktu dan ruang bagi guru menyelesaikan permasalahannya dengan bijaksana sesuai prinsip kekeluargaan sekolah.

Guru yang akan dinilai kinerjanya dari kepala sekolah adalah mereka yang harus memiliki kompetensi sebagai guru, karena dengan menilai kemampuannya mengajar sudah bisa melihat gagal tidaknya guru tersebut mengatasi problematika pembelajaran terutama dalam menghadapi anakanak berkebutuhan khusus dan regular secara bersama-sama. Ketetapan yang di tentukan kepala sekolah terhadap para guru adalah evaluasi kinerja pada waktu yang telah dijadwalkan. Pada waktu itu, para guru akan mengikuti rapat membahas hasil perkembangan mengajarnya di kelas, guru yang sulit mengatasi permasalahan akan diberikan solusi dari kepala sekolah, sedangkan guru yang mengalami penurunan kemampuan mengajarnya akan dibina kepala sekolah atau diikutkan seminar.

Kepala sekolah memiliki sikap kepemimpinan yang demokratis dengan menerima kritik saran berupa ide-ide yang berkaitan dengan keberhasilan mengajar guru. Meskipun selama proses kritik dan saran tidak semua diterima oleh kepala sekolah, karena menyangkut hasil berupa keputusan yang berdampak pada tercapainya tujuan sekolah. Kepala sekolah akan memberikan bimbingan bagi guru yang kreatif maupun yang mengalami kesulitan dengan menyediakan fasilitas belajar, pelatihan-pelatihan yang berkelanjutan.

Kepala sekolah yang selalu mengizinkan para guru untuk menuangkan ide mereka terkadang bisa menjadi permasalahan atau hambatan jika semangat guru memberikan ide tidak diterima kepala sekolah, sehingga ada beberapa guru yang sulit menerima ide keputusan kepala sekolah yang mengharuskan guru menggunakannya pada kegiatan mengajar yang dinilai guru tidak diperlukan. Beberapa guru mengalami kesulitan dalam 
(Strategi Kepala SD-LB dalam Meningkatkan Kinerja Guru)

$\overline{\text { menghadapi anak-anak berkebutuhan khusus yang selalu berubah-ubah }}$ perilakunya meski secara akademis, mereka hanya membutuhkan 30\% nilai akademis dan tidak perlu seperti anak regular yang 70\% harus mendapatkan target akademis. Tetapi, menghadapi ABK (anak berkebutuhan khusus) sulit dilakukan jika guru juga mengalami permasalahan dan mengganggu konsentrasi mengajar. Selain itu, guru yang berusia 35 tahun ke atas sulit memahami media yang menggunakan teknologi yang selalu divariasikan sekolah. Sekolah memberikan dukungan kepada para guru dalam hal fasilitas mengajar seperti media pembelajaran yang selalu bervariasi sesuai perkembangan saat ini. Selain itu, guru selalu difasilitas kegiatan seminar dan studi banding untuk menambah wawasan mereka dan meningkat kinerjanya, dan guru juga mendapatkan arahan dan pembinaan dari kepala sekolah apabila permasalahan guru bisa diselesaikan melalui kepala sekolah dan guru saja. Seperti halnya wawancara guru sebelumnya, kepala sekolah menyatakan bahwa pihak sekolah juga mendukung guru secara maksimal dalam hal yang berkaitan kinerja mengajarnya. Sekolah memfasilitasi guru dengan perlengkapan mengajar, kebebasan guru mengkreasikan pembelajaran dengan caranya sendiri, mengirim guru mengikuti seminar dan studi banding, mengundang para narasumber untuk memberikan pengarahan bagi guru, sampai pada pengarahan langsung dari kepala sekolah terhadap guru secara kekeluargaan.

Strategi kepala sekolah dalam meningkatkan kinerja para guru di SD-LB Bina Autis Mandiri Palembang dari awal perencanaan, pengaplikasian dan evaluasi kinerja menggunakan strategi sesuai tipe situasional atau situasi permasalahan dari kebutuhan masing-masing guru, selanjutnya juga menerapkan strategi reward and punishment berupa penghargaan/ imbalan atas kerja keras guru meningkatkan kemampuannya dan sanksi/ hukuman atas menurunnya kinerja guru setelah melalui berbagai cara sekolah memperbaikinya. Penerapan kepemimpinan yang situasional secara demokratis dan tegas juga menjadi pengaruh kepala sekolah untuk bisa mengelola guru agar keputusan yang dibuatnya bisa diterima dengan baik oleh mereka seperti menerima ide-ide guru, melakukan pendekatan individual yang tidak otoriter serta berusaha memahami problematika guru dan juga tidak menyalahkan guru sepenuhnya dengan sanksi yang keras.

Sebagai seorang pemimpin yang mengatur organisasi sekolah, kepala sekolah adalah sosok penting yang banyak melahirkan keputusan-keputusan yang bermanfaat bagi sekolah dari ide guru maupun keputusan bersama yayasan. Dari hasil penelitian penulis yang disesuaikan dengan teori penelitian Fiedler dan Martin mengenai pendekatan kepemimpinan ditemukan 
kesesuaian dari bentuk kepemimpinan beliau adalah pendekatan situasional yang demokratis dan juga tegas (memberikan sanksi teguran), dikarenakan kepala sekolah menerapkan keputusan sesuai kebutuhan sekolah dan juga menerima beberapa ide guru. Selain itu, kepala sekolah memberikan solusi bagi guru juga disesuaikan kebutuhan guru tersebut, karena permasalahan setiap guru selalu berbeda sehingga keputusan juga disesuaikan keadaan guru yang bersangkutan seperti keputusan soluasi atas permasalahan guru.

Berbeda Pada penelitian Fitriani (2016), strategi yang kepala sekolah terapkan hanya kepemimpinan demokratis dan lebih disenangi oleh para bawahannya, sebagaimana yang dipraktekan oleh kepala SMA Negeri 1 Mutiara Kabupaten Pidie. Selain itu, Zubair (2017) dalam penelitiannya menekankan bahwa, seorang pemimpin sekolah harus jeli mengidentifikasi dan mengklasifikasikan permasalahan yang ada sehingga menjadi suatu skala prioritas pemecahan apalagi berhubungan dengan upaya meningkatkan kinerja guru. Meskipun dalam penelitiannya juga membahas beberapa strategi yang sama dengan penulis yakni memberikan pelatihan bagi guru, supervisi dan juga memberikan motivasi kepada guru.

Maka dari itu, berdasarkan hasil penelitian Fitriani (2016), Zubair (2017) dan teori David (2000) dan Fiedler-Martin dapat disimpulkan bahwasannya terdapat kesesuaian dalam strategi kepala sekolah dalam meningkatkan kinerja para guru di SD-LB Bina Autis Mandiri Palembang dari awal perencanaan, pengaplikasian dan evaluasi kinerja menggunakan strategi sesuai tipe situasional atau situasi permasalahan dari kebutuhan masingmasing guru, selanjutnya juga menerapkan strategi reward and punishment berupa penghargaan/ imbalan atas kerja keras guru meningkatkan kemampuannya dan sanksi/ hukuman atas menurunnya kinerja guru setelah melalui berbagai cara sekolah memperbaikinya. Penerapan kepemimpinan yang situasional secara demokratis dan tegas juga menjadi pengaruh kepala sekolah untuk bisa mengelola guru agar keputusan yang dibuatnya bisa diterima dengan baik oleh mereka seperti menerima ide-ide guru, melakukan pendekatan individual yang tidak otoriter serta berusaha memahami problematika guru dan juga tidak menyalahkan guru sepenuhnya dengan sanksi yang keras.

Dari awal seleksi sudah ada ketentuan pengukuran kinerja guru yang dinilai dari 4 kompetensi guru yang harus mereka miliki. Sedangkan, apabila dalam prakteknya ditemui adanya permasalahan dalam kinerja guru, maka kepala sekolah akan mengupayakan pembinaan kepada guru baik secara intern (pembinaan langsung kepala sekolah) maupun secara ekstern yakni 
(Strategi Kepala SD-LB dalam Meningkatkan Kinerja Guru)

seminar, studi banding atau mengundang narasumber dari luar untuk memberikan pengarahan di SD-LB Bina Autis Mandiri Palembang.

Sejalan dengan teori Robbins dan penelitian dari Paida (2015) bahwa dalam organisasi ditentukan oleh kualitas guru di dalamnya. Robbins menyatakan bahwa perilaku organisasi terkait perkembangan maupun kemajuan di dalamnya sangat bergantun pada kinerja professional tenaga pekerja yang ada di dalamnya. Dan relevan dengan penelitian Paida (2015) bahwa kemajuan dan perkembangan yang dialami oleh SMKN 4 Makassar sangat didukung oleh kinerja guru itu sendiri. Kinerja guru tidak terlepas dari pengaruh faktor kompetensi dan motivasi dari sekolah. Menurut Karo-Karo (2018), dalam penelitiannya menyatakan bahwa untuk mencapai kinerja guru, mereka harus menguasai keempat kompetensi keguruan meskipun kenyataannya guru belum mampu menguasai keempat kompetensi sehingga menjadi salah satu penyebab hasil kinerja guru termasuk dalam kategori sedang dan harus ditingkatkan.

Sejalan juga dengan penelitian Zuhriyah (2015) yang menyatakan bahwa kompetensi guru berpengaruh berpengaruh positif dan signifikan terhadap kinerja guru SMK Negeri kelompok Pariwisata Program Produktif di Daerah Istimewa Yogyakarta dan secara umum dalam kategori cukup Berbeda dengan penelitian Zubair (2017) yang menyatakan bahwa kinerja guru ditekankan pada program pelatihan dan diklat serta evaluasi dan monitoring untuk mengetahui pengukuran kinerja guru yang bersangkutan. Empat kompetensi dasar guru akan bisa ditingkatkan melalui program pelatihan yang diberikan sekolah. Sedangkan penelitian penulis, kepala sekolah menerapkan program pelatihan, pembinaan, evaluasi dan juga motivasi berupa reward and punishment terhadap kinerja guru. Penelitian Raddana (2013) juga menyatakan perbedaan bahwa penelitiannya menunjukkan bahwa kinerja guru sangat berhubungan dengan motivasi dan kepuasan guru. Oleh karena itu, dalam upaya untuk meningkatkan kinerja guru, kedua aspek tersebut (motivasi dan kepuasan guru) harus mendapat perhatian. Hal ini dapat memperbaiki tujuan utama dari sertifikai guru yaitu peningkatan mutu pendidikan yang diikuti oleh perbaikann kesejahteraan (The money follow function)

Penelitian Hayati (2019) juga berbeda dengan penulis, Rita mengemukakan bahwa kinerja dipengaruhi oleh kedisiplinan guru dan juga oleh kegiatan pelatihan serta supervisi yang berkesimbungan agar para guru menyadari tupoksinya sebagai pendidik yang harus memiliki kompetensi untuk bisa dinilai baik sebagai pendidik. Beberapa hasil penelitian dan teori yang menyatakan bahwa kinerja guru adalah salah satu tolak ukur untuk 
melihat seberapa baiknya kualitas guru tersebut. Dasar utama yang harus dimiliki guru adalah kemampuan guru itu sendiri meliputi kompetensi pedagogik, professional, kepribadian dan sosial. Kurang cakapnya guru menguasai kompetensi akan memberikan dampak penilaian terhadap kualitas dirinya sebagai seorang guru.

Sejalan dengan Hayati (2019) yang menyatakan bahwa motivasi sekolah terhadap guru sangatlah berpengaruh besar bagi kinerja guru yang bersangkutan. Pemberian pelatihan yang intens serta motivasi berupa penghargaan bagi guru turut menjadi pendukung dalam antusias guru meningkatkan kemampuannya. Sama halnya dengan pendapat Mayasari (2018) dalam penelitiannya menyebutkan bahwa kepala sekolah berperan untuk mendukung guru meningkatkan kinerjanya melalui pelatihan, pengarahan, evaluasi dan juga supervisi yang berkesinambungan agar lebih mudah mengukur kinerja guru secara berkala.

Dari hasil wawancara penulis sebelumnya, dijumpai pendukung dalam strategi kepala sekolah meningkatkan kinerja guru SD-LB Bina Autis Mandiri Palembang berupa fasilitas sekolah baik dalam hal perlengkapan mengajar serta menyediakan sarana pembinaan bagi guru atas dasar wewenang penuh kepala sekolah dari yayasan. Selain itu, guru-guru yang menerima keputusan kepala sekolah melalui rapat bersama berdasarkan hasil dari ide-ide guru yang dijadikan dasar terbentuknya keputusan.

Meskipun pada prakteknya juga dijumpai hambatan dalam menerapkan strategi kepala sekolah dalam meningkatkan kinerja guru di SD-LB Bina Autis Mandiri Palembang dari sisi yang sebagian besar justeru dari guru sendiri. Penulis menemukan bahwa penghambat yang cukup siginifikan terjadi adalah ketika guru yang kesulitan konsentrasi mengajar dan dipindahkan ke bagian kantor administrasi ternyata memberikan dampak bagi kelas yang kekurangan tenaga pendidik dan harus meminta guru kelas lain atau staf pengajar dari kantor untuk bisa membantu jalanannya pembelajaran. Akan tetapi, hal tersebut justeru harus menyeimbangkan lagi guru lain yang masuk ke kelas dengan suasana kelas yang harus berusaha menerima guru tersebut karena perbedaan karakteristik kelas juga tidaklah sama masing-masing jenjang terutama untuk ABK. Meskipun sudah diupayakan oleh kepala sekolah sebagai seorang pemimpin yang memang dituntut untuk bisa mengatasi permasalahan dalam organisasinya agar bisa berjalan normal kembali.

Zuhriyah (2015) pun ikut membenarkan bahwa strategi kepala sekolah terhadap kinerja guru juga dipengaruhi oleh pendukung berupa lingkungan kerja yang kondusif. Motivasi kerja guru maupun kepemimpinan kepala 
(Strategi Kepala SD-LB dalam Meningkatkan Kinerja Guru)

$\overline{\text { sekolah yang bersama-sama memberikan dukungan terhadap guru untuk }}$ memaksimalkan lagi kemampuan dalam dirinya.

Berbeda dengan penelitian Fitriani (2016) yang menyebutkan faktor yang mempengaruhi strategi kepala sekolah terhadap kinerja guru yakni program yang digunakan kepala sekolah sebagai wujud dari kemampuannya sebagai pemimpin yang berkompeten dan juga disiplin guru serta waktu kepala sekolah monitoring dan supervisi, dana untuk kegiatan pelatihan dan sarana prasarana yang diberikan sekolah sangat bepengaruh terhadap kinerja guru.

Sejalan dengan Mayasari (2018) yang memberikan penjelasan berbeda terhadap hambatan strategi kepala sekolah dalam meningkatkan kinerja guru. Ia menyatakan bahwa yang menjadi faktor-faktor penghambat yang dihadapi kepala sekolah antara lain rendahnya kualitas guru, kurangnya kesadaran guru dalam menegakkan kedisiplina dan rendahnya kesadaran siswa terhadap kedisiplinan. Maka, sebagai seorang pemimpin di institusi pendidikan harus memiliki kemampuan dalam mengelola organisasi perihal penetapan keputusan dengan didasarkan pada sistematika manajemen strategi dari awal perumusan perencanaan, pengaplikasian hingga evaluasi strategi untuk keputusan yang dibuat. Karena kesalahan dalam menyusun strategi bisa berakibat pada keputusan yang tidak berdasarkan situasi kebutuhan organisasi dan berdampak negatif pada sulitnya mencapai tujuan organisasi yang diharapkan bersama-sama.

\section{KESIMPULAN}

Strategi yang digunakan kepala sekolah dalam meningkatkan kinerja guru di SD-LB Bina Autis Mandiri Palembang yaitu dengan melakukan seleksi ketat guru-guru melalui tes akademik dan juga pembekalan medis. Selain itu, kepala sekolah menerapkan strategi kepemimpinan situasional yang demokratis dengan menerima kritik, saran dari setiap guru-guru yang efektif bagi proses pembelajaran, kepala sekolah memberikan pelatihan-pelatihan yang persuasif kepada guru, dan kepala sekolah juga menggunakan strategi pendekatan individual bagi guru untuk dibina dan diarahkan langsung dalam upaya meningkatkan strategi guru tersebut. Kinerja guru di SD-LB Bina Autis Mandiri Palembang cukup baik melalui penilaian kompetensi guru (pedagogik, professional, individual dan sosial) saja meskipun latar belakang mereka tidak ada yang dari lulusan pendidikan anak berkebutuhan khusus. Selain itu, kinerja guru diukur melalui hasil evaluasi dari supervisi kepala sekolah dan dibahas dalam pertemuan mingguan untuk mengetahui perkembangan kemampuannya sebagai pendidik di SD-LB Bina Autis Mandiri Palembang. 
Faktor pendukung dan penghambat strategi kepala sekolah dalam meningkatkan kinerja guru, untuk pendukung yakni guru yang memiliki ide dan kreatifitas dalam mengelola proses pembelajaran, fasilitas sekolah berupa media belajar dan pelatihan yang persuasif bagi guru, sikap demokratis kepala sekolah yang menerima kritik dan saran guru, serta pemberian reward atau penghargaan bagi guru meliputi umroh dan pemberian tambahan honor. Untuk penghambat berasal dari faktor intern guru (kurang termotivasi dalam memberikan ide), usia guru yang sulit memahami media teknologi, permasalahan pribadi guru yang terbawa sampai pada aktifitas belajar mengajar dan berdampak pada kurangnya konsentrasi di kelas. Dari reward punishment ini, ada bentuk motivasi di dalamnya, karena melalui hal itu ada pemicu atau pendorong bagi guru untuk lebih baik dan maksimal lagi mengajnya.

\section{DAFTAR PUSTAKA}

Aisyah, S. (2016). Manajemen Kepemimpinan Kepala Sekolah Efektif pada Sekolah Inklusif. Islamic Education Manajemen, 1 (1).

Asiah, S. (2017). Efektifitas Kinerja Guru. Manajemen Pendidikan Islam , 4 (2). Baharuddin. (2019). Manajemen Strategik Mutu Pendidikan. Idaarah , III (1).

Damayanti, T. (2016). Kompetensi Guru Dalam Proses Pembelajaran Inklusi pada Guru SDN Negeri Kota Bandung. Psychology Research, 5 (1).

David, F. R. (2000). Strategic Management: Concepts and Cases. South Carolina: Francis Marion University.

Fitriani. (2016). Strategi Kepala Sekolah Dalam Meningkatkan Kinerja Guru Di SMA Negeri 1 Mutiara. Adm. Pendidikan , 4 (2).

Hayati, R. (2019). Kepemimpinan Kepala Sekolah dalam Meningkatkan Kinerja Guru. Prosiding Seminar Nasional Universitas PGRI Palembang.

Jannah, M. (2013). Problematika Guru Pembimbing Khusus dalam Penyelenggaraan Program Pembelajaran Individual Bagi Anak Berkebutuhan Khusus Di SDN 14 Koto Panjang. Ilmu Pendidikan , 4 (3).

Karo-Karo, D. (2018). Hubungan Antara Kepemimpinan Kepala Sekolah dengan Hasil Kinerja Guru SD Negeri Di Kecamatan Percuit Sei Tuan. SEJ, 8 (4).

Madjid, A. (2016). Pengembangan Kinerja Guru Melalui: Kompetensi, Komitmen dan Motivasi Kerja. Yogyakarta: Samudra Biru.

Mayasari, E. (2018). Strategi Kepala Sekolah dalam Meningkatkan Kompetensi Guru terhadap Hasil Belajar Siswa di SMA Negeri 1 Peukan Bada Aceh Besar. Kajian Ilmu-Ilmu Keislaman, 4 (1). 
(Strategi Kepala SD-LB dalam Meningkatkan Kinerja Guru)

Paida, A. (2015). Pengaruh Kompetensi Pedagogik, Kompetensi Profesional dan Kepuasan Kerja Terhadap Kinerja Guru Di SMK Negeri 4 Makassar. Kajian Ilmu-Ilmu Keislaman, 1 (1).

Raddana. (2013). Faktor-Faktor yang Mempengaruhi Kinerja Guru SMA Negeri Di Nusa Tenggara Barat (NTB). DIA, Administrasi Publik, 11 (2).

Rais, M. (2019). Pengaruh Diklat terhadap Kinerja Guru Madrasah di Kota Manado, Al-Qalam, 25 (1).

Sholawati, S. A. (2019). Manajemen Pembelajaran Pendidikan Inklusi pada Anak Berkebutuhan Khusus di SDN Kalirungut I Surabaya. Pendidikan Madrasah Ibtidaiyah , 2, (4).

Sugiyono. (2012). Metode Penelitian Pendekatan Kuantitatif, Kualitatif, dan $R \& D$. Bandung: Alfabeta

Taufiqurokhman. (2016). Manajemen Strategik. Jakarta: Universittas Prof. Dr. Moestopo Beragama.

Wahyusumidjo. (2008). Kepemimpinan Kepala Sekolah. Jakarta: Rajawali Pers. Widyawati, Y. (2019). The Description of Teachers' Stressor And Manifestation of Special Needs Teacherr In Inclusive And Special Schools In Jakarta. Psychology and Instruction , 3 (1).

Zubair, A. (2017). Manajemen Peningkatan Kinerja Guru. Manajer Pendidikan, $11(4)$

Zuhriyah, S. (2015). Faktor-faktor yang Mempengaruhi Kinerja Guru SMK Negeri Kelompok Pariwisata di Daerah Istimewa Yogyakarta. Literasi, VI (2). 
